\title{
Prohibition against off-label drug promotion challenged
}

$\mathrm{W}$

hen a medication approved for one malady is used for another, everyone in the health care delivery chain - drugmaker, clinic, doctor, patient - is suddenly on shaky ground.

With the stroke of a prescribing pen, the physician takes an educated guess that drug A will help condition B. Carefully crafted regimens of safety and efficacy testing results are set aside. Intuition rules.

And often, the patient's health, not to mention the fortunes of pharmaceutical companies, rides on the result.

Those stakes are in play in a lawsuit brought against the United States government by the maker of megestrol acetate (Megace ES), which is used to stimulate appetite in AIDS patients. Although approved for that purpose, the drug is in even higher demand to combat wasting in cancer patients and the elderly.

Fearing heavy fines for marketing the drug outside sanctioned purposes, Par Pharmaceutical, Inc., based in Woodcliff Lake, New Jersey, has gone to court to try to keep the feds off its back. The case is the latest to challenge regulation of health-related marketing, and recent experience has not been smooth for the government.

In 2011, the Supreme Court struck down a trend-setting state law that prohibited drug companies from using the prescribing records of individual patients to market drugs to their doctors. In another case now winding its way up the courts, Washington has hit a wall with its plan, modelled after Canada's, to require large, graphic warnings on cigarette packs.

The lawsuits are being closely watched because off-label drug use is rampant in the US, and legal. An estimated one in five medications is used for an unapproved purpose. In nursing homes, the vast majority of claims billed to the government for atypical antipsychotic drugs are for off-label treatments, according to a federal inspector general's report (http://oig.hhs .gov/oei/reports/oei-07-08-00150.pdf).

Physicians are free to prescribe drugs off-label, provided they initiate such prescriptions. It is a crime for manufacturers to promote any drug for unapproved therapies, punishable by fines that are steep even for the deeppocketed pharmaceutical industry. Witness the US $\$ 1.4$ billion penalty paid by Eli Lilly in 2009 for pitching its antipsychotic drug olanzapine as a sleeping aide for dementia patients.

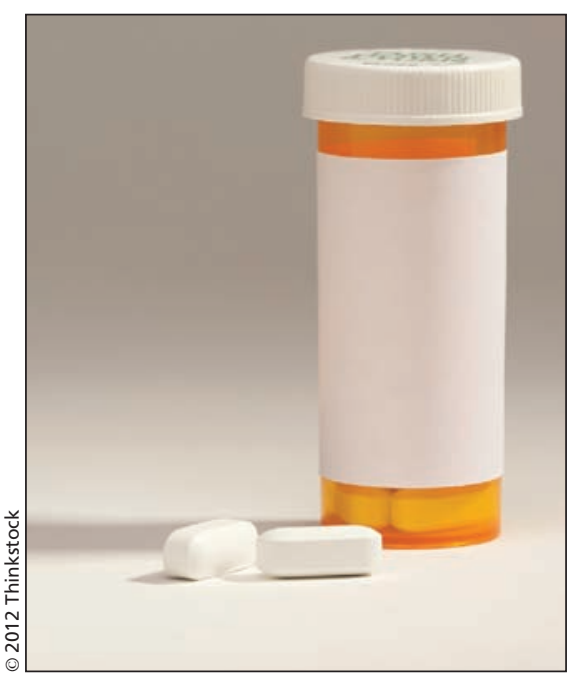

A United States drug company has launched a legal challenge to the regulatory prohibition against the promotion of drugs for off-label purposes.

The Par case has an odd twist.

The company says it wants sales representatives to promote megestrol acetate only as part of AIDS therapy (http://freepdfhosting.com/e8d67cbc9c .pdf). But it wants to be able to spread that word in long-term care facilities housing the elderly and infirm - a much larger population than the AIDS subset and a lucrative market that it cannot exploit directly.

In its brief to the US District Court, the government recites a litany of drug therapies gone wrong in asserting that the collective wisdom of doctors is no match for well-controlled clinical studies (www .elsevierbi.com/ /media/Supporting $\% 20$ Documents/The $\% 20$ Pink $\% 20$ Sheet $\% 20$ DAILY/FDA\%20response\%20to\%20Par \%20suit.pdf). Those include:

- In the 1980s, the anti-arrhythmic drugs encainide and flecainide were used to treat minor disturbances in heart rhythms after a heart attack. But clinical evaluation found patients who took the drugs faced a 2.5 times higher risk of cardiac arrest or death than those taking placebos.

- Off-label use of high-dose chemotherapy and a form of stem-cell transplantation became a widely accepted alternative to standard chemotherapy in treating metastatic breast cancer. More than 41000 people underwent the brutal treatment - which a federal official called "one of the most toxic and agonizing ever endured by patients - that raised the risk of transplant-related death.

"History thus shows that drugs and procedures accepted within the medical community as common practice or state of the art may later be shown to be unsafe or ineffective, or both - sometimes with devastating consequences to the public health," argues Dr. Rachel E. Sherman, associate director at the US Food and Drug Administration's Center for Drug Evaluation and Research.

"The number of examples in which off-label use is ineffective or harmful is simply unknown," she adds.

No particular suspicion falls on megestrol acetate. But the government argues unbridled marketing of off-label drug usage would encourage misapplied medicine and sheer profiteering.

That's why it went after Allergan for pushing the use of the wrinkle drug botulinum toxin (Botox) to treat headaches, cerebral palsy and more, and reached a US\$600 million settlement in 2010. It's also why the feds won the settlement with Eli Lilly, as well as a record US\$2.3 billion from Pfizer Inc. for misbranding its COX-2 inhibitor, valdecoxib, for off-label use.

But it hasn't been entirely clear sailing for regulators. In the Allergan settlement, the firm agreed to drop a lawsuit challenging the constitutionality of regulations on free-speech grounds.

A squabble with Big Pharma over the First Amendment isn't a fight the government is eager to pick.

But it may have no choice in Par Pharmaceutical, Inc. v. United States of America, et al. - Cal Woodward, Washington, DC.

CMAJ 2012. DOI:10.1503/cmaj.109-4128 


\section{More news online}

Press that button again, please: Brain pacemakers have the potential to make obsolete the use of drugs and other therapies in the treatment of depression (www.cmaj.ca/lookup /doi/10.1503/cmaj.109-4112). - Erin Walkinshaw, Mississauga, Ont.

Taking the pulse of pulse oximetry in Africa: A potentially inexpensive means of providing pulse oximetry using mobile phones is being tested in sub-Saharan Africa in hopes of reducing the toll taken by deaths resulting from anesthesia complications in surgeries (www.cmaj.ca /lookup/doi/10.1503/cmaj.109-4121). - Jocelyn Edwards, Kampala, Uganda

Bridging the dementia gap: The Canadian government should develop a mechanism to fund clinical trials of promising therapeutics for dementia, a neuuroscientist says (www.cmaj.ca /lookup/doi/10.1503/cmaj.109-4139).

- Sabrina Doyle, Vancouver, BC

The art of necessary compromise: Médecins Sans Frontières says it must often grapple with ethical conundrums, and make distasteful compromises, in order to provide relief in some environments (www.cmaj.ca /lookup/doi/10.1503/cmaj.109-4131). - Lauren Vogel, CMAJ

Provinces weighing HPV vaccination of boys: Provinces weighing the merits of offering human papillomavirus vaccine to boys and men aged 9-26 face a tricky trade-off between benefits and costs (www.cmaj.ca/lookup /doi/10.1503/cmaj.109-4140). - Laura Eggertson, Ottawa Ont.

Waiting for medicine's black swans: Time, tight budgets and delivery complications have emerged as major ruts in the Human Genome Project's drive toward therapeutic gold (www.cmaj .ca/lookup/doi10.1503/cmaj.109-4135). - Samantha Doyle, Vancouver, BC 